\title{
Detection of bacterial DNA in synovial fluid in dogs with arthritis: a comparison between bacterial culture and 16S rRNA polymerase chain reaction
}

\author{
Alexandra Vilén ${ }^{1^{*}} \mathbb{D}$, Bo Nilson ${ }^{2,3}$, Ann-Cathrine Petersson ${ }^{2}$, Mariana Cigut ${ }^{4}$, Christel Nielsen ${ }^{5}$ and \\ Henriette Ström ${ }^{6}$
}

\begin{abstract}
Background: Septic arthritis $(S A)$ is a serious condition in dogs that requires a prompt diagnosis and treatment to minimize long-term joint pathology. Although bacterial detection in synovial fluid (SF) through culture or cytology is often performed to confirm diagnosis, the sensitivity of these tests is low. The need for a reliable diagnostic tool to confirm the presence of bacteria in SF in humans has led to the increased use of $16 \mathrm{~S}$ rRNA (i.e., ribosomal RNA) gene sequencing by polymerase chain reaction (16S rRNA PCR). The aim of this prospective clinical study was to compare the sensitivity and specificity of 16S rRNA PCR with bacterial culture on blood agar plates after pre-incubation of SF in paediatric blood bacterial culture bottles to identify bacteria in dogs with clinical signs of SA and to investigate the usefulness of these methods as diagnostic tools.
\end{abstract}

Results: Ten dogs with clinical signs of SA, nine with osteoarthritis (OA, control group) and nine with clinical signs of immune-mediated polyarthritis (IMPA, second control group) were examined. Bacterial culture was positive in seven of 10 dogs with clinical SA, of which only two were positive by 16 S rRNA PCR. The sensitivity of $16 \mathrm{~S}$ rRNA PCR and bacterial culture analysis for dogs with clinical SA were $20 \%$ and $70 \%$, respectively. All SF samples collected from control group $(n=9)$ and second control group $(n=14)$ animals were negative on culture, and 165 rRNA PCR rendered a specificity of $100 \%$.

Conclusions: Our study showed a lower sensitivity of 16 S rRNA PCR than bacterial culture for dogs with clinical SA. Our findings suggest that there is currently no advantage in using $16 \mathrm{~S}$ rRNA PCR as a diagnostic tool for dogs with clinical SA. Furthermore, our study indicates that pre-incubation in paediatric blood bacterial culture bottles before bacterial cultivation on blood agar plates might enhance bacterial culture sensitivity compared to other culture methods.

Keywords: Canine, Incubation, Joint fluid, Paediatric blood culture bottles, Polymerase chain reaction, Septic arthritis, Synovia

*Correspondence: alexandra vilen@anicura.se

${ }^{1}$ AniCura Landskrona Small Animal Clinic, Föreningsgatan 165, 261 51 Landskrona, Sweden

Full list of author information is available at the end of the article

\section{Background}

Septic bacterial arthritis (SA) in dogs is a serious condition that requires early diagnosis and treatment for optimal outcomes. Indeed, delayed or inadequate original author(s) and the source, provide a link to the Creative Commons licence, and indicate if changes were made. The images or other third party material in this article are included in the article's Creative Commons licence, unless indicated otherwise in a credit line to the material. If material is not included in the article's Creative Commons licence and your intended use is not permitted by statutory regulation or exceeds the permitted use, you will need to obtain permission directly from the copyright holder. To view a copy of this licence, visit http://creativecommons.org/licenses/by/4.0/. The Creative Commons Public Domain Dedication waiver (http://creativecommons.org/publicdomain/zero/1.0/) applies to the data made available in this article, unless otherwise stated in a credit line to the data. 
intervention can lead to irreversible joint destruction and subsequent impaired joint function [1-3].

Staphylococcus pseudintermedius is the most commonly isolated causal agent of SA in dogs [1]; other bacteria isolated from SA include beta-haemolytic streptococci, Staphylococcus aureus, Pseudomonas aeruginosa and Escherichia coli $[1,4,5]$. Anaerobic infections have also been reported [6]. Diagnosis of SA is usually based on a combination of clinical and laboratory findings and response to antibiotic therapy $[4,7,8]$. Clinical signs of SA typically include monoarticular pain and lameness, swelling, increased heat over the affected joint, lethargy and pyrexia $[1,4,8]$. Although SA generally presents as monoarthritis, septic polyarthritis can occur, and the clinical presentation might be similar to non-infectious arthritis, such as immune-mediated polyarthritis (IMPA) $[1,9]$. Dogs with IMPA can exhibit variable clinical signs, but lameness, joint swelling, and pyrexia are commonly reported. Two or more joints should be affected [10-12]. Despite the usually rapid onset of the clinical signs, a more insidious presentation, such as IMPA, can occur with chronic or low-grade SA [1, 10-13]. Arthrocentesis is essential to differentiate between SA and IMPA, whereby the total white blood cell count (WBC) of the synovial fluid (SF) is usually dramatically increased in dogs with SA, with a predominance of neutrophils $[1,8$, $9,14]$, as in most cases of IMPA [10, 12, 13]. However, a reliable cut-off for the WBC to distinguish SA from IMPA in dogs or humans has not yet been established [15]. Analysis of SF lactate concentrations has been reported as a useful predictor of SA in both dogs [16] and humans [17]. Nevertheless, the current gold standard for diagnosing SA is the detection of bacteria in samples by cytology or a positive bacterial culture [4, 8]. Unfortunately, the diagnostic yield of these methods is suboptimal $[8,18]$, as bacteria are reportedly only detected via cytology in 16-54\% of dogs $[4,8,14,18]$ and in $19-27 \%$ of humans [19] with SA. Moreover, bacterial culture of $\mathrm{SF}$ is limited by the time required from sampling until laboratory results are ready, which is usually in the range of 3-5 days, and false negative results occur in both dogs $[1,3,4,8,18]$ and humans [20-24], at approximately $50 \%$ in the former (range of 20-50\%). Several reasons for this have been implicated, such as the recent use of antimicrobials, fastidious nature of the causative bacteria and method of sample collection [1, 3, 22]. Pre-incubation of synovia in blood culture bottles has been suggested to increase the detection sensitivity of bacteria in SF [3, 24]. To our knowledge, there are no studies on the use of paediatric blood culture bottles for diagnosing dogs. Compared to regular bottles, these bottles are adjusted for smaller sample volumes, which may be advantageous because the sample volume for dogs may be small $[4,8]$.
Additionally, there are several reports of bacterial detection and identification by $16 \mathrm{~S}$ rRNA polymerase chain reaction (PCR) for the diagnosis of SA in humans [21, 22, 25-28], with the advantage that PCR analysis does not require live bacterial culture but only bacterial DNA [20-22, 25, 26, 29-32].

Overall, there are few studies of PCR as a diagnostic tool for SA in veterinary medicine. In a study by Elmas et al. on bacterial detection in horses with septic synovitis, the sensitivity of $16 \mathrm{~S}$ rRNA PCR was significantly higher than that of bacterial culture [33]. Other studies have not found a significant difference between $16 \mathrm{~S}$ rRNA PCR and bacterial culture for horses [34] or dogs [18] with SA.

The aim of this prospective clinical study was to compare the sensitivity and specificity of 16S rRNA PCR with bacterial culture on blood agar plates after pre-incubation of synovia in paediatric blood bacterial culture bottles to identify bacteria in dogs with clinical signs of SA and to investigate the usefulness of these methods as diagnostic tools. We hypothesised that $16 \mathrm{~S}$ rRNA PCR would be more sensitive than the bacterial culture method used to detect bacteria in SF from dogs with SA. We further hypothesised that 16S rRNA PCR would have a higher specificity than bacterial culture.

\section{Methods \\ Criteria for selection of cases}

Dogs presenting at Evidensia Small Animal Referral Hospital Helsingborg, Sweden, from November 2010 to November 2013 with clinical signs of SA or IMPA were considered for this study. Dogs that were admitted for joint surgery due to degenerative osteoarthritis (OA) were considered controls, as they usually have low to normal cell counts in synovia [35]. IMPA cases were included as a second control group because of the similar clinical features to SA cases [10-13]. The inclusion criteria for the SA group were clinical signs of infectious monoarthritis (monoarticular pain and lameness, swelling with or without lethargy and/or pyrexia $[1,4,8])$ in combination with elevated leucocytes $\left(\geq 20 \times 10^{9}\right.$ cells/ $\mathrm{mL})$ and neutrophils $(\geq 20 \%)$ in SF $[1,4,35]$. Inclusion criteria for the control group were signs of mono- or polyarthropathy due to degenerative disease and low SF leucocyte $\left(<5 \times 10^{9}\right.$ cells $\left./ \mathrm{mL}\right)$ and neutrophil $(<10 \%)$ counts [35]. For the secondary control group (IMPA), inclusion criteria were clinical signs of inflammatory polyarthritis (lameness and joint swelling of two or more joints with or without pyrexia [10-13]) in combination with elevated SF leucocytes $\left(\geq 5 \times 10^{9}\right.$ cells $\left./ \mathrm{mL}\right)$ and neutrophils $(\geq 12 \%)$ in $\geq 2$ joints [10-13]. A further requirement for inclusion in all groups was that at least $0.8 \mathrm{~mL}$ synovia could be collected from a minimum of one joint of each 
patient to obtain enough SF for cytology, bacterial culture and $16 \mathrm{~S}$ rRNA PCR. Exclusion criteria were other serious illnesses, such as signs of septic polyarthritis.

Data regarding breed, weight, sex, age, duration of symptoms, affected joints, prior surgery within 6 months, and prior treatment with antimicrobials within 6 months were collected. A total of 10 dogs were found to meet the inclusion criteria for the SA group, with nine each for the control group and second control group.

\section{Collection of SF}

Arthrocentesis was performed while the dogs were under general anaesthesia and using strict aseptic conditions. A minimum of $0.2 \mathrm{~mL}$ of the collected SF intended for $16 \mathrm{~S}$ rRNA PCR was immediately transferred to a sterile container, which was placed at $-20^{\circ} \mathrm{C}$ within $30 \mathrm{~min}$. Additionally, at least $0.2 \mathrm{~mL} \mathrm{SF}$ was transferred to an EDTA tube (S-Monovette ${ }^{\circledR}$ K3 $1.2 \mathrm{~mL}$, Sarstedt, Germany) for cytological examination (Gram stain) and a manual cell count (Bürker chamber, $25 \mu \mathrm{L}$ SF diluted in $475 \mu \mathrm{L}$ saline). A minimum of $0.3 \mathrm{~mL}$ SF was injected into a paediatric blood bacterial culture bottle containing medium enriched with soybean-casein digest broth and $\mathrm{CO}_{2}$ (Bactec Peds Plus ${ }^{\mathrm{TM}}$, Becton Dickinson and Company, Sparks, MD, USA). The syringe was flushed with culture medium before the needle was withdrawn from the bottle. The blood culture medium was incubated at $37{ }^{\circ} \mathrm{C}$ for 19-24 h before inoculation onto a blood agar plate $\left(500 \mathrm{~mL}\right.$ blood agar base $\left(\mathrm{CM} 0055 \mathrm{~B}\right.$, Oxoid ${ }^{\mathrm{TM}}$, Thermo Fisher Scientific Inc., UK) with $16 \mathrm{~mL}$ bovine blood in sodium citrate, Håtunalab $\mathrm{AB}$, Bro, Sweden) [3]. The blood agar plate was subsequently incubated at $37^{\circ} \mathrm{C}$ for $24 \mathrm{~h}$; negative cultures were incubated for another $24 \mathrm{~h}$. The collected and frozen SF samples for DNA analyses were stored at $-20{ }^{\circ} \mathrm{C}$ until transport (in $-20{ }^{\circ} \mathrm{C}$ ) to a clinical microbiologic laboratory (Clinical Microbiology, Region Skåne, Lund). The samples were stored for a maximum of 6 months before they were sent in bulk. Biomedical analysts employed at Evidensia Small Animal Referral Hospital Helsingborg performed all cytological examinations of joint fluid as well as the bacterial cultures and susceptibility testing.

\section{Broad-range PCR}

SF was subjected to $16 \mathrm{~S}$ rRNA gene PCR. The analysis was performed as previously described [36]. DNA was extracted from $200 \mu \mathrm{L}$ fluid using a Bio Robot EZ-1 with DNA Tissue Kit (Qiagen, Hilden, Germany) after treatment with Proteinase $\mathrm{K}$ according to instructions by the manufacturer. Amplification was carried out in $50 \mu \mathrm{L}$ of reaction mixture containing $1 \times \mathrm{PCR}$ buffer (Qiagen), $2 \mathrm{mM} \mathrm{MgCl} 2,200 \mu \mathrm{M}$ of each dNTP, $1.25 \mathrm{U}$ HotStar Taq DNA polymerase (Qiagen), $10 \mathrm{pmol}$ of each primer and
$5 \mu \mathrm{L}$ template. P515f (5'-TGC CAG CMG CCG CGG TWA T-3') [37] and P1067r (5'-AAC ATY TCA CRA CAC GAG CT-3') [36] were used as primers for PCR and sequencing. A pre-PCR step of $15 \mathrm{~min}$ at $95^{\circ} \mathrm{C}$ was followed by 40 cycles of $93{ }^{\circ} \mathrm{C}$ for $50 \mathrm{~s}, 52{ }^{\circ} \mathrm{C}$ for $50 \mathrm{~s}$ and $72{ }^{\circ} \mathrm{C}$ for $50 \mathrm{~s}$ and a final step of $5 \mathrm{~min}$ at $72{ }^{\circ} \mathrm{C}$. Tubes with no target DNA and Haemophilus influenzae DNA were included as negative and positive controls, respectively. Both strands of the approximately 520-bp PCR product were sequenced using BigDye Terminator Cycle Sequencing Kit (Applied Biosystems Inc., Foster City, USA) and analysed using an ABI PRISM 3100 Genetic Analyzer (Applied Biosystems Inc. by BM-Labbet, Furulund, Sweden). For species identification, sequences were compared to databases available at the National Centre for Biotechnology Information using the BLAST similarity search program (www.ncbi.nlm.nih.gov).

\section{Blood sample}

A complete blood cell count $(\mathrm{CBC})$ was performed for all dogs. C-reactive protein (CRP) was analysed in $8 / 10$ dogs in the SA group and 5/9 dogs in the second control group; CRP was not analysed in the control group.

\section{Statistical methods}

Data were not normally distributed, and descriptive statistics are thus presented as the median and interquartile range. Statistical comparison of groups was performed using non-parametric Kruskal-Wallis and Mann-Whitney U tests.

The sensitivity and specificity of bacteriological culture and $16 \mathrm{~S}$ rRNA PCR were calculated according to inclusion criteria in each set of dogs. Clinical symptoms and synovial cell counts were used to establish the gold standard for each group. Associated confidence intervals were constructed using a binomial distribution to reach exact estimates. Variables indicating whether bacteriological culture and $16 \mathrm{~S}$ rRNA PCR correctly classified each joint as positive or negative according to the gold standard were created and compared using the McNemar test for paired samples. The mid-p version of the McNemar test [38] was chosen, as the number of discordant pairs was low.

Statistical significance was set at $\mathrm{P}<0.05$. All analyses were performed using SAS Enterprise Guide 6.1 (SAS Institute Inc., Cary, NC, USA).

\section{Results}

SA

Most of the dogs were large to giant breeds based on weight (Table 1). The median duration of clinical signs was 2.5 days (ranging from 0 to 365 days). The most affected joints were the elbow $(n=3)$ and stifle $(n=3)$, 
Table 1 Clinical characteristics

\begin{tabular}{|c|c|c|c|}
\hline & $\begin{array}{l}\text { Septic arthritis } \\
n=10\end{array}$ & $\begin{array}{l}\text { Second control group (IMPA) } \\
\mathrm{n}=9\end{array}$ & $\begin{array}{l}\text { Control group (OA) } \\
n=9\end{array}$ \\
\hline Age (months) & $38(26-90)^{\mathrm{a}}$ & $61(51-72)$ & $12(11-42)$ \\
\hline Weight (kg) & $42(30-47)$ & $33(30-35)$ & $39(26-45)$ \\
\hline \multicolumn{4}{|l|}{ Blood sample } \\
\hline White blood count $\left(\times 10^{9}\right.$ cells $\left./ \mathrm{L}\right)$ & $12(6-18)$ & $16(11-19)$ & $9(6-10)$ \\
\hline $\mathrm{CRP}(\mathrm{mg} / \mathrm{L})$ & $\begin{array}{l}n=8 \\
72(39-110)\end{array}$ & $\begin{array}{l}n=5 \\
89(55-97)\end{array}$ & Not evaluated \\
\hline Synovial fluid & $n=10$ & $n=27$ & $\mathrm{n}=9$ \\
\hline Leucocytes ( $\times 10^{9}$ cells/L) & $125(65-150)$ & $58(34-90)$ & $0(0-1)$ \\
\hline Neutrophils (\%) & $88(72-93)$ & $86(74-89)$ & $1(0-3)$ \\
\hline Small monocytes (\%) & $1(0-3)$ & $2(1-7)$ & $2(1-7)$ \\
\hline Large monocytes (\%) & $12(5-19)$ & $11(8-19)$ & $96(81-97)$ \\
\hline
\end{tabular}

n: Number; CRP: Canine reactive protein

${ }^{a}$ Median (inter-quartile range)

Clinical characteristics (signalment, blood parameters and synovial fluid cell count) of the three different groups included, i.e., dogs with clinical signs of septic arthritis, dogs with clinical signs of immune-mediated polyarthritis (IMPA, second control group) and the control group of dogs with signs of osteoarthritis (OA)

Table 2 Microbiological data

\begin{tabular}{lll}
\hline Pathogen & $\begin{array}{l}\text { Positive by bacterial } \\
\text { culture }\end{array}$ & $\begin{array}{l}\text { Positive } \\
\text { by PCR }\end{array}$ \\
\hline Beta-haemolytic streptococci & 3 & 2 \\
Staphylococcus pseudintermedius & 2 & 0 \\
Staphylococcus aureus & 1 & 0 \\
Pasteurella spp. & 1 & 0 \\
\hline
\end{tabular}

PCR: 16S rRNA polymerase chain reaction

Number of positive bacterial cultures and $16 \mathrm{~S}$ rRNA polymerase chain reaction analyses for dogs with signs of septic arthritis. Seven of 10 dogs with signs of septic arthritis had a positive bacterial culture, two of which were also positive by $16 \mathrm{~S}$ rRNA polymerase chain reaction analysis

followed by the shoulder $(\mathrm{n}=2)$, hock $(\mathrm{n}=1)$ and carpus $(n=1)$. Four dogs had undergone surgery on the affected joint less than 6 months prior. One joint was infected by a bite wound. Four dogs had a history of treatment with antibiotics in the last 6 months.

Positive bacterial cultures were obtained in seven cases, with four different bacterial isolates identified. Positive 16S rRNA PCR was obtained in two cases, both of which were also positive by bacterial culture (Streptococcus spp.) (Table 2). Positive bacterial cultures but negative 16S rRNA PCR results were obtained for the four dogs treated with antimicrobials.

\section{Control group}

Nine dogs were included in the control group. Most of the dogs were large to giant breeds based on weight (Table 1). SF was collected from the elbow $(n=7)$, stifle $(n=1)$ and shoulder $(n=1)$. Bacterial culture and $16 \mathrm{~S}$ rRNA PCR were performed for all nine cases, and the results were negative.

\section{Second control group}

Nine dogs were included in the second control group (IMPA), and most were large to giant breeds based on weight (Table 1). The median duration of clinical signs was 1 day (range $0-10$ days). A total of 27 joint taps were performed (hock $n=14$, carpus $n=8$, stifle $n=3$, elbow $\mathrm{n}=2$ ). None of the dogs had been treated with systemic antimicrobials in the last 6 months.

A manual cell count was performed on $26 / 27$ samples (for one case, there was only enough material for a smear). Bacterial culture and PCR were performed for $14 / 27$ samples, and both were negative for all nine dogs. Although a few solitary gram-positive cocci were identified in one culture, there were too few to be classified to the species level culture, and the laboratory report noted that their presence was of no clinical relevance.

CRP was elevated in all dogs tested $(n=8)$ with clinical signs of SA and in 4 of 5 dogs with clinical signs of IMPA (Table 1). There was no significant difference in CRP between the dogs diagnosed with SA and those diagnosed with IMPA ( $\mathrm{P}=0.94$ Mann-Whitney test).

This study found 16S rRNA PCR to be a less sensitive diagnostic method for detecting bacteria in SF in dogs with SA compared to the bacterial culture method. The sensitivity of $16 \mathrm{~S}$ rRNA PCR to detect bacteria in SA was only $20 \%$ ( $2 / 10$ dogs) compared to $70 \%$ (7/10 dogs) for bacterial culture. Furthermore, the combination of 16S rRNA PCR and culture did not improve sensitivity. The specificity of $16 \mathrm{~S}$ rRNA PCR and the culture method were both $100 \%$, as all analysed joints in the two control groups were negative (Table 3 ). 
Table 3 Statistical comparison

\begin{tabular}{lll}
\hline & Sensitivity $\mathbf{( 9 5 \% ~ C l )}$ & Specificity $\mathbf{( 9 5 \% ~ C l )}$ \\
\hline Bacterial culture & $70(35-93)$ & $100(85-100)$ \\
PCR & $20(3-56)$ & $100(85-100)$ \\
Bacterial culture+PCR & $70(35-93)$ & $100(85-100)$
\end{tabular}

$\mathrm{Cl}$ : Confidence interval are exact based on the binomial distribution PCR: 16S rRNA polymerase chain reaction

Statistical comparison of sensitivity and specificity of bacterial culture and $16 \mathrm{~S}$ rRNA polymerase chain reaction and the combination of bacterial culture and $16 \mathrm{~S}$ rRNA polymerase chain reaction to demonstrate bacteria in the synovial fluid in dogs with suspected septic arthritis

\section{Discussion}

To our knowledge, a very limited number of studies applying16S rRNA analysis for SF from dogs have been performed. The sensitivity of $16 \mathrm{~S}$ rRNA PCR for diagnosing SA in our study was $20 \%$. This was considerably lower than previously published sensitivities in veterinary medicine (73.7 to $89.5 \%$ ) [18, 33, 34]. In humans, sensitivity ranges from 23.5 to $96.2 \%$, and there are conflicting reports in the literature regarding whether 16S rRNA PCR improves diagnostics when diagnosing SA [21, 22, 27].

In our study, we employed a well-established primer pair for 16S rRNA [36] used by many clinical laboratories for human diagnostics. To our knowledge, no previous study has evaluated this primer pair for use in SF from dogs.

There are several factors that might explain the low sensitivity we observed. 16S rRNA PCR involves several critical steps, such as DNA extraction and PCR amplification, and false negative results are reportedly not uncommon, especially if only a few bacteria are present [30, 39-42].

To avoid contamination during extraction of DNA, which could cause false positive results, procedures following good laboratory practice for molecular identification of bacterial DNA were applied in this study. Proteinase $\mathrm{K}$ was used in the process of DNA extraction, which is common in DNA extraction protocols to avoid contamination resulting in false positive results. Proteinase $\mathrm{K}$ digests contaminating proteins and protects nucleic acids from degrading enzymes [30]. Nonetheless, contaminating DNA is present in many reagents used for DNA extraction, and it has been suggested that it is not possible to eliminate DNA contamination without a significant decrease in sensitivity [41].

SF contains PCR inhibitors that may cause false negative results. This is due to the natural compounds in SF as well as the high viscosity in combination with the ionic and macromolecular contents [30]. Unfortunately, the processes used to remove these inhibitors may also destroy or dilute any bacteria present $[23,30]$.

The Qiagen column we used has a limited capacity to bind DNA; in human patients with sepsis, it has been suggested that leucocyte DNA might compete with bacterial DNA, which could lead to false negative results [43]. All dogs in the SA group had a high leucocyte count in SF (median $125 \times 10^{9}$ cells $/ \mathrm{mL}$, range 65-150), which might explain why bacterial DNA was not identified as expected in the present study.

Antimicrobial treatment has been suggested to inhibit bacterial culture as well as PCR analysis, but this does not seem to explain our results. Four dogs in the SA group received antimicrobials within 6 months prior to SF sampling. All of them were positive by culture but negative by $16 \mathrm{~S}$ rRNA PCR.

Protocols regarding the collection, handling, storage and transport of samples by the human clinical microbiology laboratory that performed all $16 \mathrm{~S}$ rRNA PCR analyses in our study were followed, and there were no known deviations from these protocols. Nevertheless, failures in methodology need to be considered, as the correct handling of samples after collection is critical when using molecular techniques [41]. All samples for 16S rRNA PCR analysis were frozen within 30 min after collection and stored at $-20{ }^{\circ} \mathrm{C}$. Freezing clinical samples is considered standard and often performed prior to DNA analysis [33, 41], but there are some studies on the effect of storage on bacterial content in SF. For example, Carlsen et al. showed that the Mycoplasma genitalium DNA load decreased after storage at $-20{ }^{\circ} \mathrm{C}$ for up to 18 months, which was especially notable with clinical specimens compared to frozen DNA extracts [44]. In addition, freezing aqueous solutions of DNA samples at $-20{ }^{\circ} \mathrm{C}$ might have a negative effect on DNA stability [45]. In our study, DNA was not extracted before storage, and this cannot be ruled out as having a negative effect on our test material.

There are several limitations in our study. The sample size was small. The difficulty in obtaining a larger number of dogs with SA might be due to a combination of SA being uncommon and because some of the dogs presented with clinical signs of SA, with cytological findings that supported the diagnosis but an insufficient total sample volume. All samples in this study were collected by the veterinary surgeon on duty, with varying experience in performing a joint tap, as SA is a clinical emergency. Low sample volume in dogs with SA has previously been reported in a study where samples could not be obtained in $23.5 \%$ of cases, even by an experienced surgeon [4].

All samples in the control group were negative by both culture and $16 \mathrm{~S}$ rRNA PCR. We included a second control group of dogs with IMPA in addition to 
the control group to further rule out false positive samples. Earlier studies of $16 \mathrm{~S}$ rRNA PCR on SF in dogs have described the presence of bacteria based on $16 \mathrm{~S}$ rRNA PCR analyses in normal stifles of dogs as well as in dogs with stifle pathology traditionally considered to be non-infectious [46-49]. Additionally, a wide variety of bacteria with uncertain significance have been identified in in human patients with rheumatoid arthritis, mostly comprising gut and skin commensals, as well as some species not previously described [50,51]. All cultured samples in the second control group were negative except for one in which a small number of solitary cocci were identified. This finding was discarded by the laboratory as contamination and considered to have no clinical relevance. All analysed samples in the two control groups were negative for $16 \mathrm{~S}$ rRNA PCR, yielding a specificity of $100 \%$.

In future studies on 16S rRNA PCR sensitivity in dogs with SA, it would be valuable to compare the different published 16S rRNA primer pairs to see if any pair result in higher sensitivity than the others. It would also be valuable to obtain a larger sample size and a confirmed diagnosis of SA. Unfortunately, as previously mentioned, a cut-off value for the number of WBCs in synovia has not been established to separate infectious from inflammatory, non-infectious arthritis [15]. This correlated well with our findings, as there was no significant difference in WBC between dogs with SA and dogs with IMPA $(\mathrm{P}=0.35)$. The same conclusion was made regarding CRP, with no significant difference between these two groups of dogs $(\mathrm{P}=0.94)$. Analysis of SF lactate concentration in our study might have helped to more clearly define cases of suspected SA [16].

The current gold standard to diagnose SA is the detection of bacteria in samples by cytology or a positive bacterial culture $[4,8]$. In our study, bacterial culture of SF was positive in $70 \%$ of dogs with presumed SA. This is considerably higher than the usually reported sensitivity of approximately $50 \%[3,52]$. Pre-incubation of synovia in blood culture bottles before culture on blood agar plates has been suggested to improve results [3, 24], but the results are not consistent [52]. The improved sensitivity in our study is thought to be due to the use of preculture incubation of synovia in paediatric blood culture bottles, instead of in standard bottles, before culture on blood agar plates. The use of paediatric blood culture bottles (Bactec Peds Plus ${ }^{\mathrm{TM}}$, Becton Dickinson and Company, Sparks, MD, USA) requires smaller sample volumes than with standard bottles. Small sample volumes are, as previously mentioned, common for dogs [4]. By using complete bottle culture systems instead of agar plates, the sensitivity may improve even more. In a recent study by Cohen et al., culture in bottles (Bactec ${ }^{\circledR}$ method) showed growth in $113 / 148$ cases (76.4\%) compared to $96 / 154$ (62.3\%) with agar plate cultures [24].

Although 16S rRNA PCR may allow for a more rapid result regarding the presence of bacteria in synovia [21, $22,33]$, more studies are needed before this analysis can be considered routine for the diagnosis of SA in dogs. To be a useful diagnostic tool, 16S rRNA PCR must have a high sensitivity and be reliable. The advantage of a positive bacterial culture is not only the confirmation of bacteria but also the possibility of obtaining a susceptibility report that can ultimately lead to the best treatment plan.

\section{Conclusion}

The main finding in this study is that the sensitivity of $16 \mathrm{~S}$ rRNA PCR was considerably lower than that of the bacterial culture method used. Currently, there is not enough evidence to routinely include $16 \mathrm{~S}$ rRNA PCR in the diagnostic work-up for dogs with suspected SA. We further conclude that pre-incubation in paediatric blood bacterial culture bottles prior to agar plate culture improves sensitivity and should be considered a routine method for these patients.

\section{Acknowledgements \\ The assistance provided by Dr. Torkel Falk and Karin Löfqvist was greatly appreciated.}

\section{Authors' contributions}

AV was responsible for the study, including the processing of the data and writing the manuscript. HS aided in the planning of the study design and in writing the manuscript. MC aided in the study design and in the laboratory work at the Evidensia Small Animal Referral Hospital. BP and ACP were responsible for the DNA analyses and wrote the section on DNA analysis. $\mathrm{CN}$ performed the statistical analyses and contributed to the drafting of the manuscript. All authors read and approved the final manuscript.

\section{Funding}

Thure F och Karin Forsbergs stiftelse, Michael Forsgrens stiftelse and stiftelsen svensk djursjukvård.

\section{Availability of data and materials}

The data sets during and/or analysed during the current study are available from the corresponding author upon reasonable request.

\section{Declarations}

Ethics approval and consent to participate

The Ethics Committee on Animal Experiments for the Malmö/Lund Region, Sweden, approved this prospective clinical study. Written dog owner consent was collected in all cases.

\section{Consent for publication}

Available on request.

\section{Competing interests}

The authors declare that they have no competing interests.

\section{Author details}

${ }^{1}$ AniCura Landskrona Small Animal Clinic, Föreningsgatan 165, 26151 Landskrona, Sweden. ${ }^{2}$ Department of Clinical Microbiology, Region Skåne, Sölvega$\tan 23,22362$ Lund, Sweden. ${ }^{3}$ Section of Medical Microbiology, Department of Laboratory Medicine Lund, Lund University, Sölvegatan 23, 22362 Lund, Sweden. ${ }^{4}$ Evidensia Small Animal Referral Hospital of Helsingborg, Bergavägen 
3, 25466 Helsingborg, Sweden. ${ }^{5}$ Division of Occupational and Environmental Medicine, Department of Laboratory Medicine, Lund University, 22100 Lund, Sweden. ${ }^{6}$ Öresunds Small Animal Clinic Vellinge, Kompanigatan 27, 23523 Vellinge, Sweden.

Received: 12 June 2020 Accepted: 22 August 2021 Published online: 30 August 2021

\section{References}

1. Bennett D, Taylor DJ. Bacterial infective arthritis in the dog. J Small Anim Prac. 1988;29:207-30.

2. Hewes CA, Macintire DK. Intra-articular therapy to treat septic arthritis in a dog. J Am Anim Hosp Assoc. 2011;47:280-4.

3. Montgomery RD, Long IR Jr, Milton JL, DiPinto MN, Hunt J. Comparison of aerobic culturette, synovial membrane biopsy, and blood culture medium in detection of canine bacterial arthritis. Vet Surg. 1989;18:300-3.

4. Marchevsky AM, Read RA. Bacterial septic arthritis in 19 dogs. Aust Vet J. 1999;77:233-7.

5. Bittegeko SB, Arnbjerg J, Heje NI. Infectious epiphysitis and arthritis in a puppy. J Small Anim Pract. 1993;34:571-5.

6. Hodgin EC, Michaelson F, Howerth EW, Austin F, Davis F, Haase AS. Anaerobic bacterial infections causing osteomyelitis/arthritis in a dog. J Am Vet Med Assoc. 1992;201:886-8.

7. Madruga Dias J, Costa MM, Pereira da Silva JA, Viana de Queiroz M. Septic arthritis; patients with or without isolated infectious agents have similar characteristics. Infection. 2014;42:385-91.

8. Clements DN, Owen MR, Mosley JR, Carmichael S, Taylor DJ, Bennett D. Retrospective study of bacterial infective arthritis in 31 dogs. J Small Anim Pract. 2005:46:171-6.

9. Caywood DDW, Wilson JW, O'Leary TP. Septic polyarthritis associated with bacterial endocarditis in two dogs. JAVMA. 1977;171:549-52.

10. Clements DNG, Gear RNA, Tattersall J, Carmichael S, Bennett D. Type I immune-mediated polyarthritis in dogs 39 cases (1997-2002). JAVMA. 2004;224:1323-7.

11. Bennett D. Immune-based non-erosive inflammatory joint disease of the dog.3. Canine idiopathic polyarthritis. J small Anim Prac. 1987;28:909-28.

12. Stull JW, Evason M, Carr AP, Waldner C. Canine immune-mediated polyarthritis: clinical and laboratory findings in 83 cases in western Canada (1991-2001). Can Vet J. 2008;49:1195-203.

13. Jacques D, Cauzinille L, Bouvy B, Dupre G. A retrospective study of 40 dogs with polyarthritis. Vet Surg. 2002;31:428-34.

14. Mielke B, Comerford E, English K, Meeson R. Spontaneous septic arthritis of canine elbows: twenty-one cases. Vet Comp Orthop Traumatol. 2018;31:488-93.

15. McGillicuddy DC, Shah KH, Friedberg RP, Nathanson LA, Edlow JA. How sensitive is the synovial fluid white blood cell count in diagnosing septic arthritis? Am J Emerg Med. 2007;25:749-52.

16. Proot JL, de Vicente F, Sheahan DE. Analysis of lactate concentrations in canine synovial fluid. Vet Comp Orthop Traumatol. 2015;28:301-5.

17. Shu E, Farshidpour L, Young M, Darracq M, Ives TC. Utility of point-of-care synovial lactate to identify septic arthritis in the emergency department. Am J Emerg Med. 2019;37:502-5.

18. Scharf VF, Lewis DD, Wellehan JF, Wamsley HL, Richardson R. Comparison of synovial fluid culture and 16S rRNA PCR in dogs with suspected septic arthritis. Aust Vet J. 2015;93:204-7.

19. Souza Miyahara H, Helito CP, Oliva GB, Aita PC, Croci AT, Vicente JR. Clinical and epidemiological characteristics of septic arthritis of the hip, 2006 to 2012, a seven-year review. Clinics. 2014;69:464-8.

20. Ferroni A, Al Khoury H, Dana C, Quesne G, Berche P, Glorion C, et al. Prospective survey of acute osteoarticular infections in a French paediatric orthopedic surgery unit. Clin Microbiol Infect. 2013;19:822-8.

21. Kim H, Kim J, Ihm C. The usefulness of multiplex PCR for the identification of bacteria in joint infection. J Clin Lab Anal. 2010;24:175-81.

22. Bonilla H, Kepley R, Pawlak J, Belian B, Raynor A, Saravolatz LD. Rapid diagnosis of septic arthritis using 16S rDNA PCR: a comparison of 3 methods. Diagn Microbiol Infect Dis. 2011;69:390-5.
23. Trampuz A, Osmon DR, Hanssen AD, Steckelberg JM, Patel R. Molecular and antibiofilm approaches to prosthetic joint infection. Clin Orthop Relat Res. 2003:414:69-88.

24. Cohen D, Natshe A, Ben Chetrit E, Lebel E, Breuer GS. Synovial fluid culture: agar plates vs. blood culture bottles for microbiological identification. Clin Rheumatol. 2020;39:275-9.

25. van der Heijden IM, Wilbrink B, Vije AE, Schouls LM, Breedveld FC, Tak PP. Detection of bacterial DNA in serial synovial samples obtained during antibiotic treatment from patients with septic arthritis. Arthritis Rheum. 1999;42:2198-203.

26. Yang S, Ramachandran P, Hardick A, Hsieh YH, Quianzon C, Kuroki M, et al. Rapid PCR-based diagnosis of septic arthritis by early Gram-type classification and pathogen identification. J Clin Microbiol. 2008;46:1386-90.

27. Coiffier G, David C, Gauthier P, Le Bars H, Guggenbuhl P, Jolivet-Gougeon A, et al. Broad-range 16 s rDNA PCR in synovial fluid does not improve the diagnostic performance of septic arthritis in native joints in adults: cross-sectional single-center study in 95 patients. Clin Rheumatol. 2019;38:1985-92.

28. Culbreath K, Melanson S, Gale J, Baker J, Li F, Saebo O, et al. Validation and retrospective clinical evaluation of a quantitative $16 \mathrm{~S}$ rRNA gene metagenomic sequencing assay for bacterial pathogen detection in body fluids. J Mol Diagn. 2019;21:913-23.

29. Jalava J, Skurnik M, Toivanen A, Toivanen P, Eerola E. Bacterial PCR in the diagnosis of joint infection. Ann Rheum Dis. 2001;60:287-9.

30. Mariani BD, Levine MJ, Booth RE Jr, Tuan RS. Development of a novel, rapid processing protocol for polymerase chain reaction-based detection of bacterial infections in synovial fluids. Mol Biotechnol. 1995:4:227-37.

31. Fenollar F, Roux V, Stein A, Drancourt M, Raoult D. Analysis of 525 samples to determine the usefulness of PCR amplification and sequencing of the $16 \mathrm{~S}$ rRNA gene for diagnosis of bone and joint infections. J Clin Microbiol. 2006:44:1018-28.

32. Fihman V, Hannouche D, Bousson V, Bardin T, Liote F, Raskine L, et al. Improved diagnosis specificity in bone and joint infections using molecular techniques. J Infect. 2007;55:510-7.

33. Elmas CR, Koenig JB, Bienzle D, Cribb NC, Cernicchiaro N, Cote NM, et al Evaluation of a broad range real-time polymerase chain reaction (RTP(R) assay for the diagnosis of septic synovitis in horses. Can J Vet Res. 2013;77:211-7.

34. Pille F, Martens A, Schouls LM, Dewulf J, Decostere A, Vogelaers D, et al. Broad range 165 rRNA gene PCR compared to bacterial culture to confirm presumed synovial infection in horses. Vet J. 2007;173:73-8.

35. MacWilliams PS, Friedrichs KR. Laboratory evaluation and interpretation of synovial fluid. Vet Clin North Am Small Anim Pract. 2003;33:153-78.

36. Kahn F, Linder A, Petersson AC, Christensson B, Rasmussen M. Axillary abscess complicated by venous thrombosis: identification of Streptococcus pyogenes by 16S PCR. J Clin Microbiol. 2010;48:3435-7.

37. Nikkari S, Lopez FA, Lepp PW, Cieslak PR, Ladd-Wilson S, Passaro D, et al. Broad-range bacterial detection and the analysis of unexplained death and critical illness. Emerg Infect Dis. 2002:8:188-94.

38. Fagerland MW, Lydersen S, Laake P. The McNemar test for binary matched-pairs data: mid-p and asymptotic are better than exact conditional. BMC Med Res Methodol. 2013;13:91.

39. Yamamoto Y. PCR in diagnosis of infection: detection of bacteria in cerebrospinal fluids. Clin Diagn Lab Immunol. 2002;9:508-14.

40. Louie JS, Liebling MR. The polymerase chain reaction in infectious and post-infectious arthritis. A review. Rheum Dis Clin North Am. 1998;24:227-36.

41. Corless CE, Guiver M, Borrow R, Edwards-Jones V, Kaczmarski EB, Fox AJ. Contamination and sensitivity issues with a real-time universal 16S rRNA PCR. J Clin Microbiol. 2000;38:1747-52.

42. Marin M, Garcia-Lechuz JM, Alonso P, Villanueva M, Alcala L, Gimeno M, et al. Role of universal 165 rRNA gene PCR and sequencing in diagnosis of prosthetic joint infection. J Clin Microbiol. 2012;50:583-9.

43. Jordan JA, Durso MB. Real-time polymerase chain reaction for detecting bacterial DNA directly from blood of neonates being evaluated for sepsis. J Mol Diagn. 2005;7:575-81.

44. Carlsen KH, Jensen JS. Mycoplasma genitalium PCR: does freezing of specimens affect sensitivity? J Clin Microbiol. 2010:48:3624-7.

45. Podivinsky E, Love JL, van der Colff L, Samuel L. Effect of storage regime on the stability of DNA used as a calibration standard for real-time polymerase chain reaction. Anal Biochem. 2009:394:132-4. 
46. Bhandal J, Hayashi K, Kim SY, Klein M, Wong A, Toupadakis CA, et al. Detection of bacterial DNA by PCR in dogs with stifle pathology. Vet Surg. 2013;42:814-8.

47. Muir P, Fox R, Wu Q, Baker TA, Zitzer NC, Hudson AP, et al. Seasonal variation in detection of bacterial DNA in arthritic stifle joints of dogs with cranial cruciate ligament rupture using PCR amplification of the 165 rRNA gene. Vet Microbiol. 2010;141:127-33.

48. Muir P, Oldenhoff WE, Hudson AP, Manley PA, Schaefer SL, Markel MD, et al. Detection of DNA from a range of bacterial species in the knee joints of dogs with inflammatory knee arthritis and associated degenerative anterior cruciate ligament rupture. Microb Pathog. 2007;42:47-55.

49. Schwartz Z, Zitzer NC, Racette MA, Manley PA, Schaefer SL, Markel MD, et al. Are bacterial load and synovitis related in dogs with inflammatory stifle arthritis? Vet Microbiol. 2011;148:308-16.

50. Cox CJ, Kempsell KE, Gaston JSH. Investigation of infectious agents associated with arthritis by reverse transcription PCR of bacterial rRNA. Arthritis Res Ther. 2003;5:R1-8.
51. Siala M, Jaulhac B, Gdoura R, Sibilia J, Fourati H, Younes M, et al. Analysis of bacterial DNA in synovial tissue of Tunisian patients with reactive and undifferentiated arthritis by broad-range PCR, cloning and sequencing. Arthritis Res Ther. 2008; 10:R40.

52. Scharf VF, Lewis ST, Wellehan JF, Wamsley HL, Richardson R, Sundstrom $D A$, et al. Retrospective evaluation of the efficacy of isolating bacteria from synovial fluid in dogs with suspected septic arthritis. Aust Vet J. 2015;93:200-3.

\section{Publisher's Note}

Springer Nature remains neutral with regard to jurisdictional claims in published maps and institutional affiliations.
Ready to submit your research? Choose BMC and benefit from:

- fast, convenient online submission

- thorough peer review by experienced researchers in your field

- rapid publication on acceptance

- support for research data, including large and complex data types

- gold Open Access which fosters wider collaboration and increased citations

- maximum visibility for your research: over $100 \mathrm{M}$ website views per year

At BMC, research is always in progress.

Learn more biomedcentral.com/submissions 